ZOOLOGIA 29 (4): 375-379, August, 2012

doi: $10.1590 /$ S1984-46702012000400009

\title{
On the identity of the type species of Actinopus tarsalis (Araneae: Actinopodidae)
}

\author{
Laura T. Miglio', Sylvia M. Lucas² \& Alexandre B. Bonaldo
}

\author{
${ }^{1}$ Laboratório de Aracnologia, Museu Paraense Emílio Goeldi. Caixa Postal 399, 66017-970 Belém, PA, Brazil. \\ E-mail: lauramiglio@gmail.com; bonaldo@museu-goeldi.br \\ ${ }^{2}$ Laboratório de Artrópodes, Instituto Butantan. Avenida Vital Brasil 1500, 05503-900 São Paulo, SP, Brazil. \\ E-mail: sylvialucas@butantan.gov.br
}

\begin{abstract}
The type species of the Neotropical Actinopus, A. tarsalis Perty, 1833, is redescribed based on material from the type locality, the state of Piauí, Brazil. The species appears to be restricted to northeastern Brazil and is newly recorded from the state of Sergipe. An old record from the state of Rio Grande do Sul is rejected. Actinopus tarsalis differs from other species of the genus by details of the male copulatory bulb: tegular apophysis absent, robust embolar base, inserted basally at a right angle $\left(90^{\circ}\right)$; embolar apices apex flattened and expanded, arrow-shaped in dorsal view.
\end{abstract}

KEY WORDS. Arachnida; morphology; Mygalomorphae; Neotropical Region; taxonomy.

Actinopus was proposed by PerTy (1833), to include only the type species, Actinopus tarsalis Perty, 1833, originally described in the same occasion. This species was based on a single male collected in the state of Piauí, Brazil, by J.B. von Spix and C.F.P. Martius, who traveled through Piauí during May, 1819, collecting in the villages of Amarante and Oeiras (SpIX \& Agassiz 1829, Papavero 1971, Levi 1964). The acceptance of Actinopus as a valid genus was not immediate, since LuCAs (1837) transferred $A$. tarsalis to Pachyloscelis Lucas, 1835 and WaLckenaer (1842) to Sphodros Walckenaer, 1835. C.L. Косн (1842) revalidated Actinopus, redescribing the type species and expanding its known distribution to Uruguay. The first informative illustrations of the male copulatory bulb were provided by LucAs et al. (1978/1979), based on a single specimen from São Raimundo Nonato, Piauí.

The systematic of Actinopodidae is now relatively well established. The seminal paper by Raven (1985) placed the family among the Fornicephalae, providing the first hypothesis of monophyly for the family. Presently, three putatively monophyletic lineages are recognized: the exclusively Neotropical Actinopus, the Australian/Chilean Missulena Walckenaer, 1805 and the Chilean Plesiolena Goloboff \& Platnick, 1987. Goloboff \& Platnick (1987) provided the first set of putative synapomorphies for Actinopus. Despite the advances in recognizing these putatively monophyletic groups, the taxonomic knowledge of Actinopodidae genera, especially that of Actinopus, is far from satisfactory. The 27 presently-valid species have not yet been revised, and preliminary surveys on Neotropical material from several collections indicate that the diversity of the genus is much larger than previously expected, with nearly twice the number of currently know species waiting to be described (L.T. Miglio, personal data). The first step toward a revision of such a large genus is to establish, beyond any doubt, the identity of its type spe- cies. The holotype was not located in the Musée de Historie Naturelle, Paris and, as most Perty's material, is probably lost. However, an exhaustive search for material coming from the state of Piauí revealed a number of individuals whose characteristics are consistent with those originally described for $A$. tarsalis. These individuals are co-specific with the specimen identified as such by Lucas et al. (1978/1979). Beyond the fact that the collecting localities of Spix \& Martius in Piaui are within the area of occurrence here postulated for $A$. tarsalis in northeastern Brazil (Fig. 13), our specimens represent the only currently known species of Actinopus from Piauí (among four other morphospecies, all of them know only by males) that does not present characters fragrantly conflicting with the original description of $A$. tarsalis. We are therefore confident that the spiders presented below are co-specific with the specimen described by PERTY (1833) as $A$. tarsalis. The record of this species for Uruguay by C.L. КосH (1842) probably refers to an erroneous identification: examining material from several localities in Uruguay, as well as from nearby regions (Rio Grande do Sul, Brazil and Buenos Aires, Argentina) indicated that $A$. tarsalis do not occur there.

Unfortunately, despite our efforts in gathering relevant material, the female of $A$. tarsalis remains unknown. The lack of females may be explained by the extreme behavioral differences presented by males and females in this genus. While the males present wandering habits, been commonly collected with pitfall-traps, the females dig trapdoor burrows to ambush their prey, which they rarely abandon (Coyle et al. 1990, Brescovit et al. 2002). These natural history particularities cause a predisposition on the number of Actinopus disponible in collections, in which nearly $75 \%$ are males and virtually no vial is composed by representatives of both sexes. Interestingly CoyLe et al. (1989), suggested that females of Actinopus may be quite 
abundant, reporting the observation of 50 Actinopus burrows in a single aggregation. BREsCovit et al. (2002) indicated that usually after the first specimen has been found, other specimens are easily seen, since their burrows present a clustered distribution. However, most of the modern records of Actinopus came from structured inventories, which employ a fixed, generally time-bounded sampling protocol that consistently undersamples trapdoor spiders and other burrowing arachnids.

\section{MATERIAL AND METHODS}

The material examined belongs to the following institutions (curators in parentheses): IBSP, Instituto Butantan, São Paulo, São Paulo, Brazil (D.M. Barros Battesti); MCN, Fundação Zoobotânica do Rio Grande do Sul, Museu de Ciências Naturais, Porto Alegre, Rio Grande do Sul, Brazil (E.H. Buckup); and MPEG, Museu Paraense Emilio Goeldi, Belém, Pará, Brazil (A.B. Bonaldo).

All measurements are expressed in millimeters. Measurements of length and width of the eye area and height from the fovea were taken according to GRISWOLD \& LEDFORD (2001). The format of the description follows GRISWOLD \& LEDFORD (2001), except for the spine pattern, which follows Petrunkevitch (1925). The terminology for the structures of the copulatory bulb follows BERTANI (2000) and acronyms for the height of carapace follows GRISWOLD \& LEDFORD (2001).

Approximated latitude and longitude data for those records that were not georeferenced, were obtained from online gazetteers (Miranda \& Coutinho 2004, Fallingrain Genomics 2006). The approximate travel route of Spix and Martius through Northwest Brazil was plotted in Fig. 12 is based on Papavero (1971).

Abbreviations used in the descriptions and illustrations: (TA) tegular apophysis, (PA) paraembolyc apophysis, (PAc) prolateral accessory keel, (PI) prolateral inferior keel, (PS) prolateral superior keel, (Fe) femur, (Pa) patella, (Ti) tibia, (Me) metatarsus, (Ta) tarsus, (d) dorsal, (v) ventral, (p) prolateral, (r) retrolateral, (PME) posterior median eyes, (PLE) posterior lateral eyes, (ALE) anterior lateral eyes, (AME) anterior median eyes, (MOQ) median ocular quadrangle, (OAL) ocular area length, (OAW) ocular area width, (HF) Height from the fovea.

\section{TAXONOMY}

\section{Actinopus tarsalis Perty, 1833}

Figs 1-12

Actinopus tarsalis Perty, 1833: 198, pl. 39, fig. 6 (holotype male, Piauí, Brasil, not located in MNHN, probably lost); C.L. Koch, 1842: 101, fig. 753; Simon, 1892: 80, figs 80, 82; Lucas et al., 1978/1979: 133, figs 3-6; Platnick, 2012.

Pachyloscelis tarsalis; Lucas, 1837: 377.

Sphodros tarsalis; Walckenaer, 1842: 437.

Diagnosis. Males of Actinopus tarsalis differs from the ones of all other species of the genus by the copulatory bulb with- out a tegular apophysis and by the robust embolar base, inserted basally at a right angle $\left(90^{\circ}\right)$; embolar apex flattened and expanded, arrow-shaped in dorsal view (Figs 9-11).

Male (MPEG 11715). Total length 14.3; Carapace, long 6.51; wide 2.82. Carapace anterior region tapering. Anterior eye row slightly procurved, posterior row recurved (Fig. 1). One bristle between OMA-clypeus, few bristles distant between the PMEPME and PLE-PLE. Rastellum protuberant, inverted V-shaped, hirsute, without spines (Fig. 2). Chelicera with denticles close to the prolateral row of teeth (Fig. 3). Patella and tibia III with distal crown of well developed thorns (Figs 5 and 6). Patela III and IV with spines on prolaterodorsal face (Figs 4 and 5). Ventral scopulae occupying 50\% of the length of tarsus I, $90 \%$ to $100 \%$ of II and III and IV (Figs 7 and 8). Scopula of tarsi I and II with setae spaced, forming diffuse group of bristles. Carapace and chelicera pale brown, sternum yellowish brown, coxae, trochantera, femora and patellae pale brown, tibiae, metatarsi and tarsi pale orange, abdomen pale gray. Eyes: Diameters: PME 0.19 PLE 0.24 ALE 0.36, AME 0.34; MOQ: Length 0.92, front width 0.92, back width 1.89; Interdistances: PME-PME 1.44, PLE-PME 0.09, AME-AME 0.22, ALE-AME 0.41, ALE-PLE 0.38, AME-PME 0.37. Ocular area: OAL 2.76, OAW 3.86, and IF 1.76. Body: Clypeus: 6.51; Fovea: 2.82; Labium: lenght 0.91; width 0.87; Chelicera: lenght 3.82; width 1.59; Sternum: lenght 3.03; width 2.56; Abdomen: lenght 7.56; width 5.18. Leg measurements: I: Fe 6.14/Pa 2.64/Ti 3.48/Me 4.76/Ta 2.93/total 19.95. II: 5.94/2.48/3.43/4.97/2.88/19.7. III: 4.66/2.58/2.25/4.96/3.34/ 17.77. IV: 6.5/2.89/4.98/5.44/3.12/22.93. Formula 4123. Spinulation: I - Fe v0, d0, p0, r0; Pa v0-0-1, d0, p0, r0; Ti v4-79, d0, p0-0-2, r0-0-3; Me v10-8-11, d0, p1-2-3, r0-1-3; Ta v10-710, d0, p0-1-3, r1-3-6. II - Fe v0, d0, p0, r0; Pa v0-0-1, d0, p0, r0; Ti v4-5-8, d0, p0-0-1, r1-3-5; Me v8-11-12, d0, p0-0-2, r2-4-6; Ta v9-8-6, d0, p0-0-1, r4-3-6. III - Fe v0, d0, p0, r0; Pa v0-0-4, d710-23, p1-0-3, r0-0-3; Ti v3-3-4, d1-0-3, p0-3-4, r0-0-4; Me v5-64, d0, p0-1-3, r1-2-5; Ta v0-1-2, d0, p1-4-6, r0-4-5; IV - Fe v0, d0, p0, r0; Pa v0-0-3, d15-8-3, p0, r0; Ti v3-2-5, d0, p0-1-0, r0-0-2; Me v8-9-6, d0, p1-1-3, r0-0-1; Ta v0-0-4, d0, p0-5-9, r0-2-3. Palp: PA well developed, embolus with three small keels (Pa, PI and PS); keels evident in dorsal and retrolateral views, barely visible prolaterally. TA absent; prolateral surface of tegulum serrated next the base of the embolus (Figs 9-11).

Variation. Males $(n=10)$ : Eyes: Diameters: PME $0.17 \pm$ 0.25 , PLE $0.22 \pm 0.39$, ALE $0.34 \pm 0.5$, AME $0.3 \pm 0.43$; MOQ: Length $0.85 \pm 1.36$, front width $0.8 \pm 1.44$, back width $1.64 \pm$ 2.52; Interdistances: PME-PME $1.37 \pm 2.21$, PLE-PME $0.05 \pm 0.1$, AME-AME $0.14 \pm 0.37$, ALE-AME $0.41 \pm 0.86$, ALE-PLE $0.37 \pm$ 0.66 , AME-PME $0.32 \pm 0.67$. Ocular area: OAL $2.76 \pm 4.52$, OAW $2.7 \pm 3.87$, and IF $1.58 \pm 2.21$. Body: Total lenght: $11.09 \pm 16.38$; Carapace: lenght $4.83 \pm 7.04$; Width $4.9 \pm 6.47$; Clypeus: $0.13 \pm$ 0.26 ; Fovea: $2.12 \pm 4.06$; Labium: lenght $0.91 \pm 1.57$; Width 0.84 \pm 1.34 ; Chelicera: lenght $2.68 \pm 3.82$; Width $1.4 \pm 1.96$; Sternum: lenght $3.03 \pm 4.19$; Width $2.56 \pm 3.93$; Abdomen: lenght $5.43 \pm 7.74$; Width $3.97 \pm 6.39$. Leg measurements: I: Fe $5.58 \pm$ 

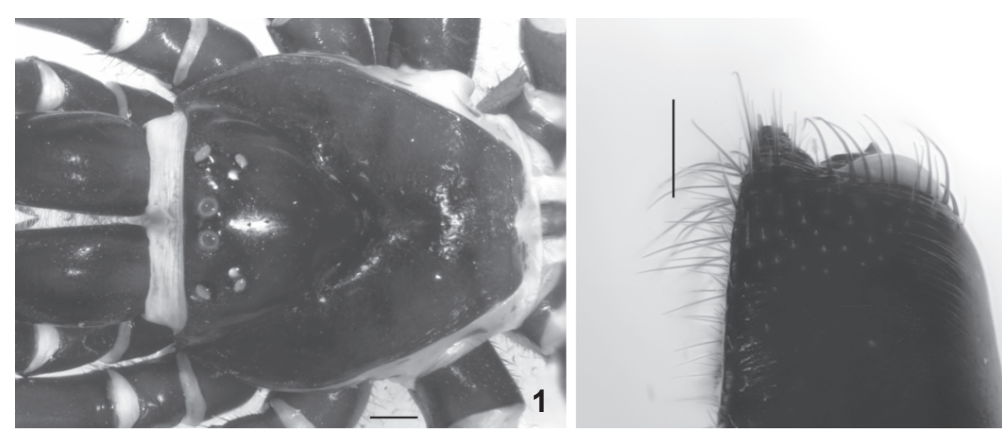

2
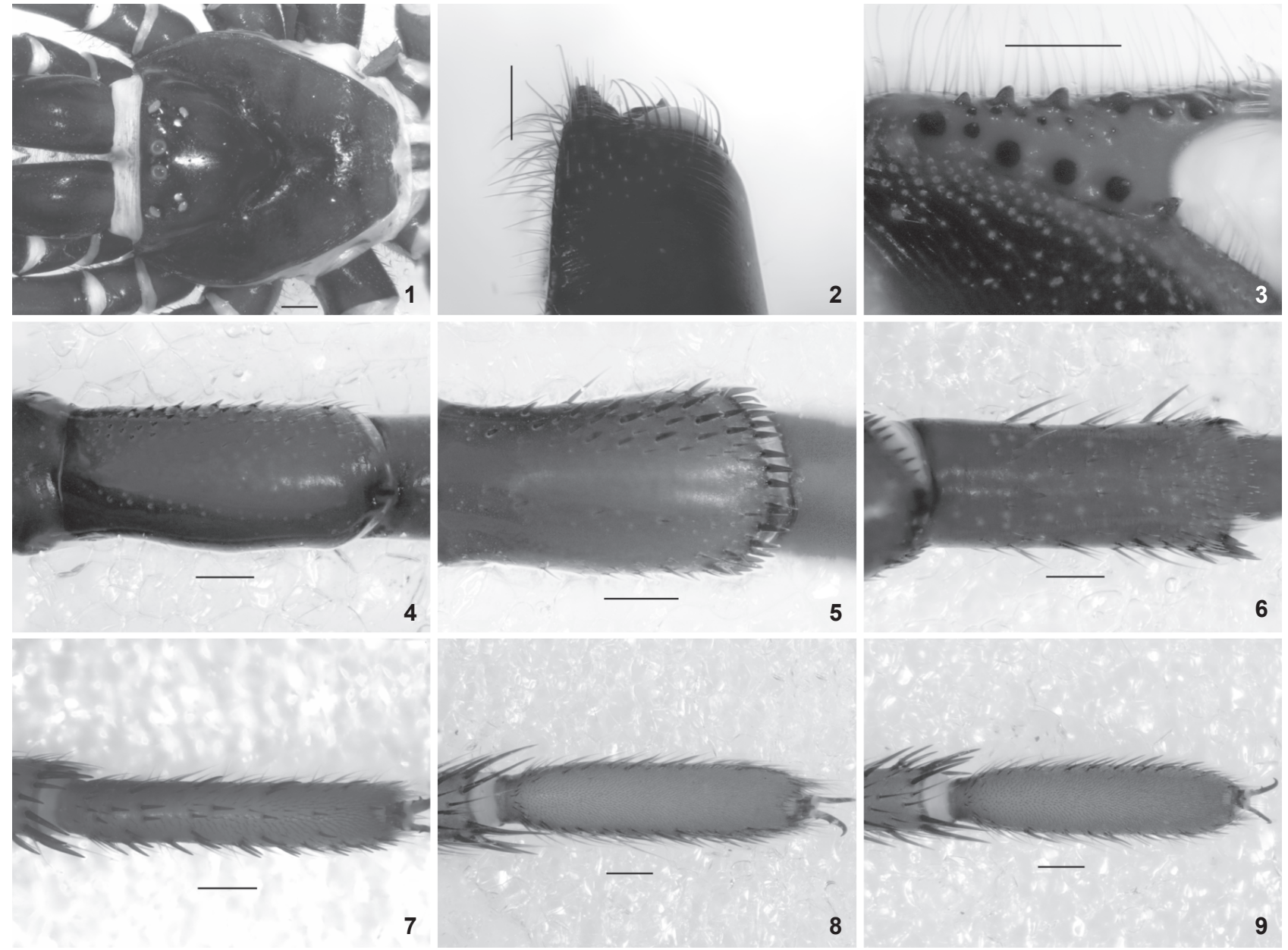

Figures 1-8. Actinopus tarsalis, male, 1-8 MPEG 11715: (1) carapace; (2) rastelum, dorsal; (3) cheliceral teeth, ventral; (4) patella IV, dorsal; (5) patella III, dorsal; (6) tibia III, dorsal; (7) scopula, tarsus II, ventral; (8) scopula, tarsus III, ventral; (9) scopula, tarsus IV, ventral. Scale bars: $0.5 \mathrm{~mm}$.

$6.71 / \mathrm{Pa} 2.25 \pm 2.82 / \mathrm{Ti} 3.48 \pm 4.44 / \mathrm{Me} 4.3 \pm 5.4 / \mathrm{Ta} 2.84 \pm 3.23 /$ total $18.19 \pm 22.6$. II: $5.37 \pm 6.68 / 2.24 \pm 2.88 / 3.07 \pm 4.17 / 4.37 \pm$ $5.59 / 2.8 \pm 3.37 / 17.89 \pm 22.69$. III: $4.26 \pm 5.33 / 2.15 \pm 3.05 / 2.08 \pm$ $3.09 / 4.38 \pm 5.79 / 2.78 \pm 3.65 / 15.65 \pm 20.85$. IV: $5.72 \pm 7.41 / 2.48$ $\pm 3.31 / 4.11 \pm 5.53 / 4.89 \pm 6.19 / 2.95 \pm 3.68 / 20.33 \pm 26.09$.

Material examined. BraziL: Piauí: Brasileira e Piracuruca, Parque Nacional de Sete Cidades, $04^{\circ} 05^{\prime} 56.3^{\prime \prime} \mathrm{S}, 41^{\circ} 05^{\prime} 56.3^{\prime \prime} \mathrm{W}$, Campo Limpo, 3 males, 15-20.IX.2006, L.S. Carvalho leg. (MPEG 2535); Cerradão, 4 males, 26.I.2007, L.S. Carvalho, M.T.L. Avelino \& M.P. Albuquerque leg. (MPEG 11715, MPEG 11717, MPEG 11718, MPEG 11720); Mata Seca Semidecídua, 2 males, 22.I.2007, L.S. Carvalho leg. (MPEG 11716); 1 male, 23.I.2007, L.S. Carvalho, M.T.L. Avelino \& M.P. Albuquerque leg. (MPEG 11719); São Raimundo Nonato, $09^{\circ} 0^{\prime} S, 42^{\circ} 41^{\prime} \mathrm{W}, 1$ male, III.1979, C.R. Russo leg. (IBSP 104407); XI.1999, F. Wolf leg. (MCN 33484); Sergipe: Canindé de São Francisco, Rio São Fran- cisco, Usina Hidrelétrica de Xingó, Área 8, 2 males, 08.VI.2000 (IBSP 114464); São Cristóvão, 1 male, 1988, (IBSP 110499).

Distribution. Known from the states of Sergipe and Piauí, Brazil. The record from Uruguay (C.L. Косн 1842) is rejected.

\section{ACKNOWLEDGMENTS}

We would like to thank to the curators of the several collections that loaned material. To Leonardo S. Carvalho and Maura Elisabeth M. Sousa for helping with the map. To José Paulo Guadanucci for trying to locate the holotype of $A$. tarsalis in MNHN. This research was supported by CNPq (grants MSc\#132732/2007-6 to LTM and PQ\#307463/2009-5 to ABB). To Programa de Pós-Graduação em Zoologia, Universidade Federal do Pará/Museu Paraense Emílio Goeldi. This article is part of first author's Master Dissertation. 


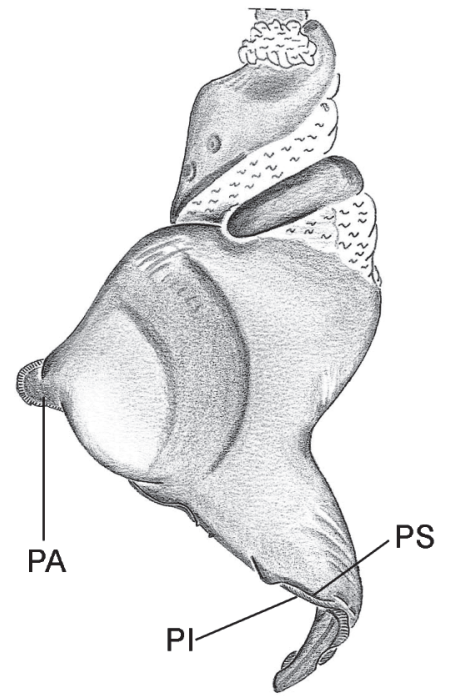

10

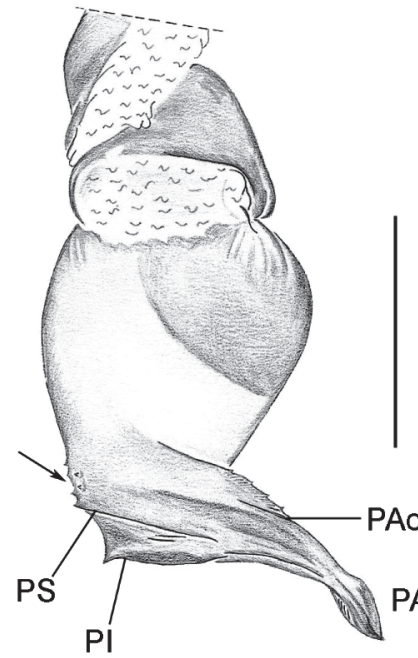

11

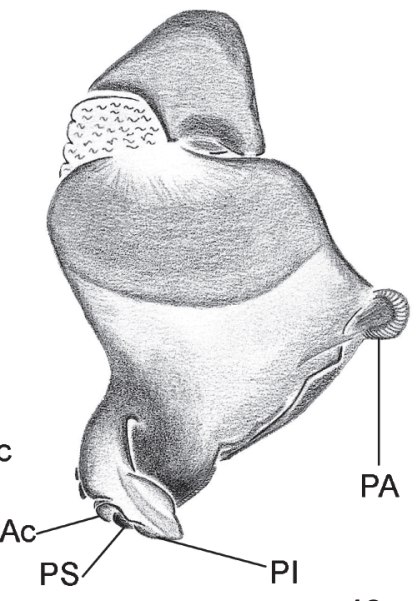

12

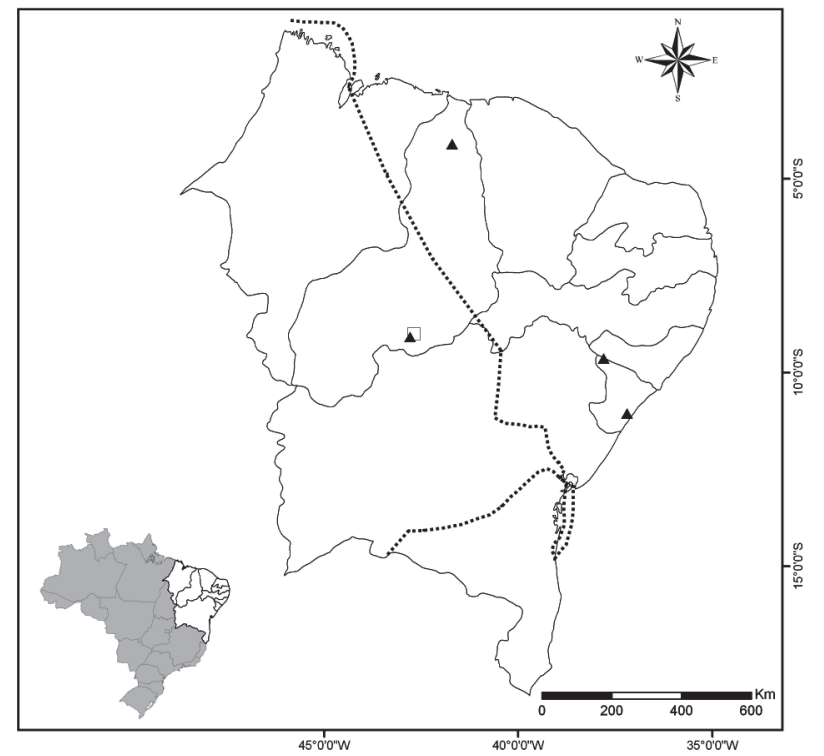

13

Figures 10-13. Actinopus tarsalis, male, 10-12 MPEG 11715: (10) copulatory bulb, prolateral; (11) copulatory bulb, dorsal; (12) copulatory bulb, retrolateral - (PA) Paraembolyc apophysis, (Pac) Prolateral accessory keel, (PI) prolateral inferior keel, (PS) prolateral superior keel. Arrow: serrated surface on prolateral tegulum; (13) known distribution of Actinopus tarsalis. The black triangles represent the records from the present paper; the white square represents the record by LucAs et al. (1978/1979). The dashed line indicates the approximated route of Spix \& Martius expedition through northeastern Brazil, based on the information gathered by PAPAVERO (1971). Scale bar: $1.0 \mathrm{~mm}$.

\section{LITERATURE CITED}

Bertani, R. 2000. Male Palpal Bulbs and Homologous Features in Theraphosinae (Araneae, Theraphosidae). The Journal of Arachnology 13: 71-78

Brescovit, A.D.; A.B. Bonaldo; R. Bertani \& C.A. Rheims. 2002.
Araneae, p. 303-343. In: J. AdIs (Ed.). Amazonian Arachnida and Myriapoda: identification keys to all classes, orders, families, some genera, and lists of known terrestrial species. Sofia, Pensoft Publishers.

Coyle, F.A.; P.A.Goloboff \& R.A. SAmson. 1990. Actinopus trapdoor spiders (Araneae, Actinopodidae) killed by the fungus, 
Nomuraea atypicola (Deuteromycotina). Acta Zoologica Fennica 190: 89-93.

Fallingrain Genomics. 2006. Global Gazetteer Version 2.1. Falling Rain Genomics, Inc. Available online at: http:// www.fallingrain.com/world [Accessed: 02/I/2009].

Goloboff, P.A. \& N.I. Platnick. 1987. A review of the Chilean spiders of the superfamily Migoidea (Araneae, Mygalomorphae). American Museum Novitates 2888: 1-15.

Griswold, C.E. \& J. LeDford. 2001. A monograph of the migid trap door spiders of Madagascar and review of the world genera (Araneae, Mygalomorphae, Migidae). Occasional Papers of the California Academy of Sciences 151: 1-120.

Косн, C.L. 1842. Die Arachniden. Nürnberg, Neunter Band, p. 57-108, Zehnter Band, p. 1-36.

LEVI, H.W. 1964. Nineteenth Century South American Araneology. Papéis Avulsos do Departamento de Zoologia 16: 9-19.

Lucas, H. 1837. Observations sur les araneides du genre Pachyloscelis, et synonymie de ce genre. Annales de la Société Entomologique de France 6: 369-392.

Lucas, S.; A. Cirelli; I. Knysak \& L. Zveibil. 1978/1979. Aracnídeos coletados no Piauí durante a realização do Projeto Rondon XXII. Memórias do Instituto Butantan 42/43: 127-138.

Miranda, E.E. \& A.C. Coutinho. 2004. Brasil Visto do Espaço. Campinas: Embrapa Monitoramento por Satélite, Ministério da Agricultura, Pecuária e Abastecimento. Available online at: http://www.cdbrasil.cnpm.embrapa.br. [Accessed: 02/I/2009].
Papavero, N. 1971. Essays on the history of Neotropical Dipterology, with special reference to collectors (17501905). São Paulo, Museu de Zoologia, Universidade de São Paulo, vol. 1, VII+216p.

Perty, M. 1833. Arachnides Brasilienses, p. 191-209. In: J.B. DE SPIX \& F.P. MARTIUS (Eds). Delectus animalium articulatorum quae in itinere per Braziliam ann. 1817 et 1820 colligerunt. Monachii.

Petrunkevitch, A. 1925. Arachnida from Panama. Transactions Connecticut Academy of Arts and Sciences 27: 51-248.

Platnick, N.I. 2012. The world spider catalog, version 4.5. American Museum of Natural History. Available online at: http://research.amnh.org/entomology/spiders/catalog/ index.html [Accessed: 02/V/2012].

Raven, R.J. 1985. The spider infraorder Mygalomorphae (Araneae): Cladistics and systematics. Bulletin of the American Museum of Natural History 182: 1-180.

Spix, J.B. von \& L. Agassiz. 1829. Selecta genera et species piscium quos in itinere per Brasiliam annos MDCCCXVIIMDCCCXX jussu et auspiciis Maximiliani Josephi I... colleget et pingendso curavit Dr J. B. de Spix... Monachii. Selecta Piscium Brasiliam: Part 1: I-XVI + I-II + 1-82.

SIMON, E. 1892. Histoire naturelle des araignées. Paris, vol. 1, p. $1-256$.

WaLCKENAER, C.A. 1842. Histoire naturelle des Insects. Aptères. Paris, vol. 2, p. 1-549.

Submitted: 17.I.2012; Accepted: 04.VI.2012.

Editorial responsibility: Antonio D. Brescovit 